\title{
A comparative study of reactivity and selectivity of chiral diamines and structurally analogous amino alcohol ligands in enantioselective alkylations with diethylzinc
}

\author{
M. Elisa Silva Serra*, Dina Murtinho and A. M. d'A. Rocha Gonsalves
}

\begin{abstract}
A series of chiral $\delta$-diamines and structurally analogous $\delta$-amino alcohols derived from natural tartaric acid were synthesized and a comparative study of their activity and selectivity in the enantioselective alkylation of aromatic aldehydes was carried out. Our results show that in general the $\delta$-diamines were found to be better chiral inducers than the corresponding $\delta$-amino alcohols. The highest selectivity was observed when benzaldehyde was alkylated in the presence of the benzylic diamine, giving $(R)-1$-phenylpropanol with an ee of $42 \%$. Copyright (C) 2008 John Wiley \& Sons, Ltd.
\end{abstract}

Keywords: enantioselective; diamine; amino alcohol; alkylation; diethylzinc; benzaldehyde

\section{Introduction}

Catalytic enantioselective reactions constitute important tools in the synthesis of chiral molecules. In particular, the alkylation of aldehydes with diethylzinc allows for the synthesis of chiral secondary alcohols of great importance in the preparation of pharmaceuticals, agrochemicals and perfumes, among others. ${ }^{[1-4]}$ In these catalytic processes a variety of ligands have been used successfully, namely, amino alcohols, diols, diamines and their derivatives.

Herein we describe the synthesis of a range of $\delta$-diamines and their analogous $\delta$-amino alcohols derived from naturally occurring $(R, R)$-tartaric acid, having the general structures presented in Fig. 1, to be tested in enantioselective alkylations with diethylzinc. Some compounds with the above-mentioned general structures have previously been described. In the diamine series, besides the unsubstituted diamine ${ }^{[5-8]}$ some derivatives with different substituents on nitrogen have been prepared: $N$-methyl, ${ }^{[8,9]} \mathrm{N}, \mathrm{N}$-dimethyl, ${ }^{[8,10]} \mathrm{N}$-cyclohexyl, ${ }^{[11]} \mathrm{N}$-benzyl, ${ }^{[12]} \mathrm{N}, \mathrm{N}$ dibenzyl ${ }^{[13]}$ and $N, N$-diphenyl. ${ }^{[9]}$ Among previously described amino alcohols are the unsubstituted amino alcohol ${ }^{[13]}$ and the $\mathrm{N}$-benzyl amino alcohol. ${ }^{[14]}$ Although these derivatives have been used in enantioselective processes such the hydrogenation of carbon-carbon double bonds, the reduction of prochiral ketones with $\mathrm{NaBH}_{4}$ and allylic alkylations, ${ }^{[10,12,13]}$ they have never, to the best of our knowledge, been tested as ligands for enantioselective alkylations with diethylzinc.

We therefore synthesized some new $\delta$-diamines and $\delta$-amino alcohols, as well as some of the known compounds, in order to carry out a comparative study of their catalytic activity and selectivity in the enantioselective alkylation of benzaldehyde. In this way we intended to determine the effect of functional groups and other structural characteristics of the ligands on their efficiency.
These compounds seemed particularly appealing due to the fact that some chiral ligands such as diphosphines, diols and amino alcohols with the same backbone structure have been described and show great efficiency in many enantioselective processes. Very good examples are DIOP, its derivatives, the TADDOLs and aminoTADDOLs (Fig. 1). ${ }^{[15-17]}$

\section{Results and Discussion}

Synthesis of chiral ligands

A series of $\delta$-diamines was prepared using diethyl-(R,R)-tartarate, $(R, R)-1$, through a four-step synthetic sequence, Scheme 1.

The protection of the hydroxyl groups was carried out by the acid-catalyzed reaction of $(R, R)$-1 with acetone to give acetonide $(R, R)$-2. Although other procedures have been described for this protection, ${ }^{[18-22]}$ our conditions are milder and the product is obtained with good yield.

Following a modified literature procedure, reduction of the ester functions of $(R, R)-\mathbf{2}$ was carried out using lithium aluminum hydride at room temperature in THF to give diol $(S, S)-3,{ }^{[19,23]}$ which was treated with tosyl chloride in pyridine at $0{ }^{\circ} \mathrm{C}$, originating the corresponding ditosylate $(S, S)-\mathbf{4}^{[8,20]}$

$(S, S)-\mathbf{4}$ was transformed into the diamine using an adapted literature procedure ${ }^{[24]}$ : reflux in isopropanol with excess of a primary or secondary amine, namely, cyclohexylamine, benzylamine

\footnotetext{
* Correspondence to: M. Elisa Silva Serra, Departamento de Química, Faculdade de Ciências e Tecnologia, Universidade de Coimbra, 3004-535 Coimbra, Portugal.E-mail:melisa@ci.uc.pt
}

Departamento de Química, Faculdade de Ciências e Tecnologia, Universidade de Coimbra, 3004-535 Coimbra, Portugal 
<smiles>[R]NC[C@H]1OC(C)(C)O[C@@H]1CN([R2])[R]</smiles>

(a)<smiles>[R]NC[C@H]1OC(C)(C)O[C@H]1CO</smiles>

(b)
Figure 1. General structure of (L)-tartaric acid derived chiral $\delta$-diamines (a) and $\delta$-amino alcohols (b).

(R)-1-phenylethylamine, (S)-1-phenylethylamine and morpholine. Chiral $\delta$-diamines $(S, S)$-5a-e were thus obtained in moderate yields.

The synthesis of several $\delta$-amino alcohols, analogues of $(S, S)-\mathbf{5}$, prepared from the common precursor, diol $(R, R)-\mathbf{3}$, was carried out according to Scheme 2. The selective tosylation of one of the hydroxyl functions ${ }^{[25]}$ in the presence of butyllithium originated $(S, S)-6$ which was purified by column chromatography to remove some of the corresponding ditosylated compound $(S, S)-\mathbf{4}$ which was also formed.

Treatment of $(S, S)-\mathbf{6}$ with sodium azide to give $(S, S)-7,{ }^{[22,26]}$ followed by hydrogenation originated amino alcohol $(S, S)-\mathbf{8}$. Alternatively, reaction of $(S, S)-\mathbf{6}$ with cyclohexylamine, (S)-1phenylethylamine, benzylamine and morpholine gave the $\delta$-amino alcohols (S,S)-9-12, respectively.

\section{Enantioselective alkylation reactions}

The efficiency of the chiral ligands synthesized was tested in the enantioselective alkylation of benzaldehyde 13 with diethylzinc, under optimized reaction conditions ${ }^{[27]}$ (Scheme 3).

Reactions were carried out at $0{ }^{\circ} \mathrm{C}$ for $24 \mathrm{~h}$ in cyclohexane using 2 equivalents of diethylzinc and $15 \mathrm{~mol} \%$ of the ligand. The results of the alkylations in the presence of $\delta$-diamines $(S, S)-\mathbf{5 a}-\mathbf{e}$ are summarized in Table 1. Under the described reaction conditions, the ligands catalyzed the alkylations with moderate conversions and enantiomeric excesses which varied from 6 to $42 \%$. With the exception of $(S, S)$-5e, all ligands originated $(R)$-1-phenylpropanol 14 as the major reaction product. The formation of benzyl alcohol as a secondary reaction product was observed. The most efficient ligand with respect to both activity and selectivity was the benzylic diamine $(S, S)-\mathbf{5 b}$, which originated $(R)-\mathbf{1 4}$ with an ee of $42 \%$.

The influence of additional chiral centers on the selectivity of this type of ligand was studied using $(S, S)-\mathbf{5} \mathbf{c}$ and $(S, S)-\mathbf{5} \mathbf{d}$. There are two new chiral centers on each of these ligands, directly bonded to the nitrogen atoms. The use of $(S, S)-\mathbf{5 c}$ and $(S, S)$-5 d originated quite different results. With $(S, S)-\mathbf{5}$ c in which the additional chiral centers have $(R)$ absolute configuration, the conversion and percentage of chiral alcohol $\mathbf{1 4}$ as well as the ee were low. With $(S, S)-\mathbf{5 d}$, in which the additional chiral centers have $(S)$ absolute configuration, the conversion and percentage of $\mathbf{1 4}$ were slightly higher and the<smiles>CCCOC[C@H]1OC(C)(C)OC1CCCC(O)C(O)C(O)C(=O)OCC</smiles>

$\begin{array}{lll}(R, R)-1 & (R, R)-\mathbf{2} & (S, S)-3\end{array}$

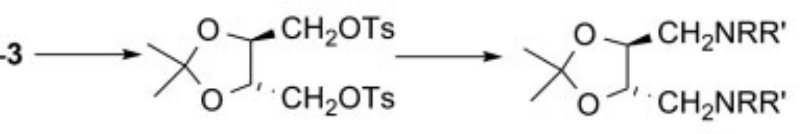

$(S, S)-4$
$(S, S)-5$ a $R=H, R^{\prime}=$ cyclohexyl

b $\mathrm{R}=\mathrm{H}, \mathrm{R}^{\prime}=$ benzyl

c $\mathrm{R}=\mathrm{H}, \mathrm{R}^{\prime}=(R)$-phenylethyl

d $\mathrm{R}=\mathrm{H}, \mathrm{R}^{\prime}=(\mathrm{S})$-phenylethyl

e $\mathrm{R}, \mathrm{R}^{\prime}=$ morpholyl

Scheme 1. Synthetic sequence for $\delta$-diamines $(S, S)-\mathbf{5}$.

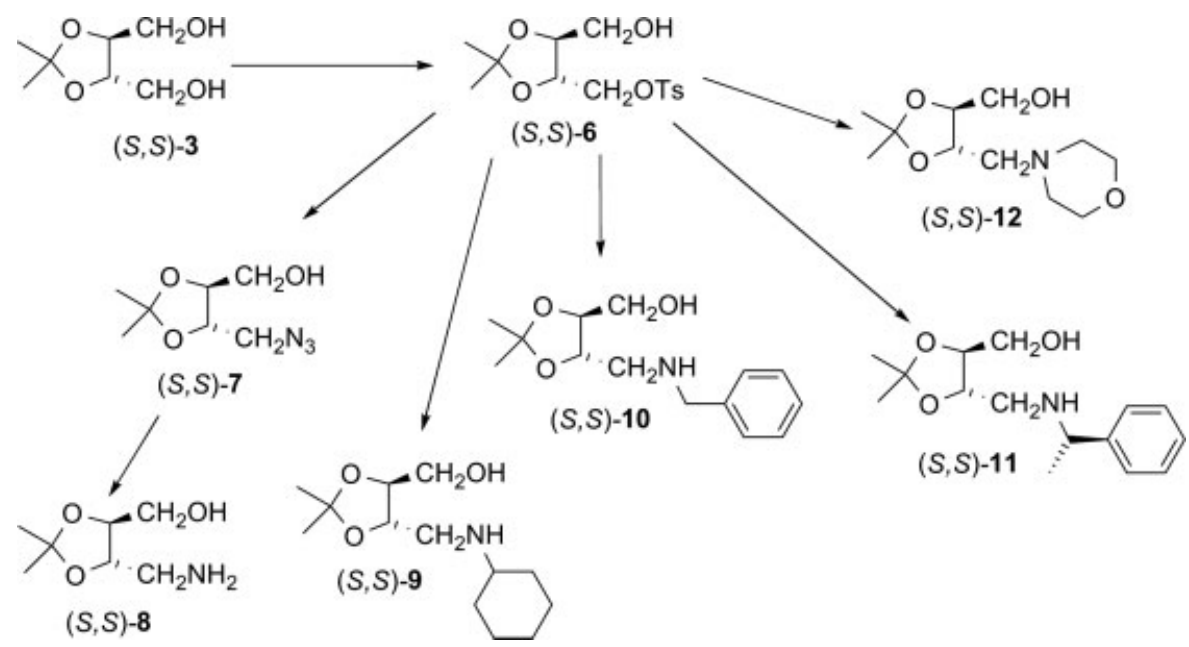

Scheme 2. Synthesis of $\delta$-amino alcohols $(S, S)-\mathbf{8}-12$. 


$$
\underset{13}{\stackrel{O}{I_{H}}}+\mathrm{ZnEt}_{2} \text { (2 eq.) } \frac{5 \mathrm{a}-\mathrm{e}, 8-12}{0^{\circ} \mathrm{C} \text {, cyclohexane }}
$$

\begin{tabular}{|c|c|c|c|}
\hline Ligand & $\begin{array}{c}\text { Conversion } \\
(\%)^{\mathrm{b}}\end{array}$ & $\begin{array}{l}\text { 1-Phenylpropanol } \\
(\%)^{\mathrm{b}, \mathrm{c}}\end{array}$ & $\begin{array}{l}\text { ee( } \%)^{d} / a b s . \\
\text { config. }\end{array}$ \\
\hline$(S, S)-\mathbf{5 a}$ & 68 & 84 & $8(R)$ \\
\hline$(S, S)-\mathbf{5 b}$ & 69 & 100 & $42(R)$ \\
\hline$(S, S)-\mathbf{5 c}$ & 42 & 57 & $8(R)$ \\
\hline$(S, S)-\mathbf{5 d}$ & 59 & 81 & $27(R)$ \\
\hline$(S, S)-\mathbf{5 e}$ & 57 & 69 & $6(S)$ \\
\hline
\end{tabular}

Scheme 3. Enantioselective alkylation of benzaldehyde 13.

a Reactions were carried out at $0{ }^{\circ} \mathrm{C}$ for $24 \mathrm{~h}$ after the addition of a 1 $M$ hexane solution of diethylzinc $(2 \mathrm{mmol})$ to $(S, S)-5(0.15 \mathrm{mmol})$ and benzaldehyde ( $1 \mathrm{mmol}$ ) in cyclohexane. ${ }^{\mathrm{b}}$ Determined by GC. ${ }^{\mathrm{C}}$ Relative to converted benzaldehyde. ${ }^{\mathrm{d}}$ Determined by chiral GC analysis.

ee was significantly better, $27 \%$. The results seem to indicate a pronounced mismatched effect of chiral centers in $(S, S)-\mathbf{5 c}$, which is not as evident in $(S, S)-\mathbf{5 d}$.

The modest enantiomeric excesses observed with this class of ligands may be explained by some flexibility of the cyclic transition state, a seven-membered chelate, which may contribute to the formation of less active and selective catalytic complexes.

The enantioselective alkylations carried out in the presence of $\delta$-amino alcohols $(S, S)-\mathbf{8 - 1 2}$, Table 2 , resulted in conversions and percentages of chiral alcohol $\mathbf{1 4}$ which were generally lower than those observed with the corresponding $\delta$-diamines. These ligands are not as active as their diamine counterparts and the optical yields of the products are all less than $10 \%$ and practically independent of the overall ligand structure. The presence of one hydroxyl and only one amine functionality, instead of two, may have significantly decreased steric factors which contribute to more selective catalytic species.

The enantiomeric excesses obtained with chiral ligands $(S, S)$ 5a-e and (S,S)-8-12 are much lower than those which result from the use of structurally similar ligands, namely the TADDOLs which show high selectivities in enantioselective transformations. ${ }^{[17]}$

Table 2. Enantioselective addition of diethylzinc to benzaldehyde in the presence of $(S, S)-\mathbf{8}-12^{\mathrm{a}}$

\begin{tabular}{|lccc|} 
Ligand & $\begin{array}{c}\text { Conversion } \\
(\%)^{\mathrm{b}}\end{array}$ & $\begin{array}{c}\text { 1-Phenylpropanol } \\
(\%)^{\mathrm{b}, \mathrm{c}}\end{array}$ & $\begin{array}{c}\text { ee(\%) } \\
\text { config. }\end{array}$ \\
\hline$(S, S)-\mathbf{8}$ & 57 & 74 & $3(S)$ \\
$(S, S)-\mathbf{9}$ & 55 & 71 & $8(S)$ \\
$(S, S)-\mathbf{1 0}$ & 55 & 36 & $8(R)$ \\
$(S, S)-\mathbf{1 1}$ & 83 & 70 & $<1$ \\
$(S, S)-\mathbf{1 2}$ & 56 & 61 & $9(R)$ \\
\hline
\end{tabular}

a Reactions were carried out at $0{ }^{\circ} \mathrm{C}$ for $24 \mathrm{~h}$ after the addition of a $1 \mathrm{M}$ hexane solution of diethylzinc $(2 \mathrm{mmol})$ to the ligand $(0.15 \mathrm{mmol})$ and benzaldehyde $(1 \mathrm{mmol})$ in cyclohexane. ${ }^{\mathrm{b}}$ Determined by GC. ${ }^{\mathrm{C}}$ Relative to converted benzaldehyde. ${ }^{d}$ Determined by chiral GC analysis.
Table 3. Enantioselective addition of diethylzinc to aromatic aldehydes in the presence of $(S, S)-5 \mathbf{b}^{a}$

\begin{tabular}{lccc} 
Aldehyde & $\begin{array}{c}\text { Conversion } \\
(\%)^{\mathrm{b}}\end{array}$ & $\begin{array}{c}\text { Chiral } \\
\text { alcohol }(\%)^{\mathrm{b}, \mathrm{c}}\end{array}$ & $\begin{array}{c}\text { ee(\%) } / \text { abs. } \\
\text { config. }^{-}\end{array}$ \\
\hline Benzaldehyde & 69 & 100 & $42(R)$ \\
1-Naphthaldehyde & 62 & 81 & $6(R)$ \\
o-Methoxybenzaldehyde & 74 & 91 & $20(S)$ \\
m-Methoxybenzaldehyde & 66 & 77 & $20(R)$ \\
p-Methoxybenzaldehyde & 30 & 64 & $13(R)$ \\
o-Chlorobenzaldehyde & 80 & 93 & $15(S)$ \\
p-Chlorobenzaldehyde & 73 & 83 & $31(R)$ \\
\hline
\end{tabular}

a Reactions were carried out at $0{ }^{\circ} \mathrm{C}$ for $24 \mathrm{~h}$ after the addition of a 1 $\mathrm{M}$ hexane solution of diethylzinc $(2 \mathrm{mmol})$ to $(S, S)-\mathbf{5 b}(0.15 \mathrm{mmol})$ and aldehyde $(1 \mathrm{mmol})$ in cyclohexane. ${ }^{\mathrm{b}}$ Determined by GC. ${ }^{\mathrm{C}}$ Relative to converted aldehyde. ${ }^{d}$ Determined by chiral GC analysis.

This difference is most probably due to the presence of substituents on $C^{1}$ and $C^{4}$. The steric crowding caused by these substituents, usually bulky phenyls, strongly favors the predominant coordination by one of the aldehyde faces in the reaction transition state so that a product with high selectivity results. Although $(S, S)$-5a-e have two bulky groups, their position does not seem to be the most suitable for high discrimination of the enantiotopic aldehyde faces in the transition state.

Using $(S, S)-\mathbf{5 b}$, which showed the highest selectivity in the alkylation of benzaldehyde 13, we carried out the alkylation of a variety of other aromatic aldehydes (Table 3).

All of the substituted aldehydes gave the corresponding chiral alcohols with lower ee than benzaldehyde $\mathbf{1 3}$ itself. Conversions and percentages of chiral alcohol were slightly lower for the $p$-substituted aldehydes, while they were highest when the electron-attracting chlorine substituent was present.

Under our reaction conditions and with the substrates studied, we found that the alkylation with $(S, S)$-5b mostly gave $(R)$ alcohol as the major enantiomer, resulting from coordination of the $R e$ face of the aldehyde. However, the ortho substituted aldehydes originated $(S)$ alcohols. This may be due to some additional steric hindrance in these cases, which forces the aldehydes to coordinate with the Si face.

\section{Conclusions}

Synthetic procedures for the preparation of tartaric acid-derived chiral $\delta$-diamines $(S ; S)-\mathbf{5 a}-\mathbf{e}$ and their structurally analogous $\delta$ amino alcohols $(S ; S)-\mathbf{8 - 1 2}$ have been established. When these chiral ligands were used in the enantioselective alkylation of aldehydes with diethylzinc, the $\delta$-diamines demonstrated greater activity and selectivity than their $\delta$-amino alcohol counterparts. The ligand showing greatest efficiency was the benzylic diamine $(S, S)-5 b$, originating alkylation products with ee up to $42 \%$.

Further studies on the application of these ligands in other enantioselective transformations are underway.

\section{Experimental}

\section{General}

All solvents were dried prior to use following standard procedures. Reactions were carried out in an inert atmosphere using standard 
Schlenk-type techniques. Diethylzinc (Aldrich) was used as a 1 $M$ solution in hexane. Benzaldehyde was distilled prior to use and stored over $4 \AA$ molecular sieves. Commercially acquired cyclohexylamine, $(R)$-1-phenylethylamine, $(S)$-1-phenylethylamine, benzylamine and morpholine were stored over $\mathrm{KOH}$.

Melting points were determined using a Leitz-Wetzler 799 microscope with a heated plate (values are uncorrected). Optical rotations were measured with an Optical Activity AA- 5 polarimeter. NMR spectra were recorded on a Bruker AMX 300 (300 and $75.5 \mathrm{MHz}$ for ${ }^{1} \mathrm{H}$ and ${ }^{13} \mathrm{C}$, respectively). The solvent was $\mathrm{CDCl}_{3}$. TMS was used as the internal standard and chemical shifts are given in $\delta$. Elemental analyses were carried out on a Fisons Instruments EA 1108 CHNS-O elemental analyzer. GC analyses were recorded on an HP 5890A instrument coupled to an HP 3396A integrator using a capillary column (Supelcowax 10, 30 m, 0.25 i.d., $0.25 \mu \mathrm{m}$ ). Infrared spectra were recorded on a Perkin Elmer 1720X FTIR (liquids and oils were processed as films and solids as $\mathrm{KBr}$ pellets). Mass spectra were recorded on an HP 5973 MSD chromatograph with $70 \mathrm{eV}$ (El), Agilent 6890 series, equipped with an HP-5MS column $(30 \mathrm{~m} \times 0.25 \mathrm{~mm} \times 0.25 \mu \mathrm{m})$ or on a Fisons Instruments-Platform with an APCI probe coupled to a ThermoSeparation SpectraSeries P200 chromatograph.

Alkylation reaction products were identified by comparison with authentic commercially acquired samples and by GC/MS analysis. Catalytic experiments were repeated in order to confirm results. Enantiomeric excesses were determined by using a chiral $\gamma$ cyclodextrin capillary column (FS-Lipodex-E, $25 \mathrm{~m}, 0.25$ i.d.) from Machery-Nagel using hydrogen as carrier gas, on an HP $5890 \mathrm{~A}$ instrument coupled to an HP 3396A integrator. The absolute configuration of the major enantiomers was determined by comparison of the retention times with reported values and by determining the sign of the optical rotation of the isolated reaction. ${ }^{[28-31]}$

\section{Synthesis of $(S, S)-2,3-0-$-Isopropylidene- $N^{1}, N^{4}$-butane-1,4- diamines}

Diethyl-(R,R)-2,3-O-isopropylidene tartarate $[(R, R)-\mathbf{2}]$

To diethyl- $(R, R)$-tartarate $(0.4 \mathrm{~mol}, 68.4 \mathrm{ml})$ in acetone $(200 \mathrm{ml})$, triethylorthoformate $(0.8 \mathrm{~mol}, 133 \mathrm{ml})$ and $p$-toluenesulfonic acid (40 mg) were added and the reaction mixture refluxed to complete conversion, determined by GC chromatography. After evaporation of the acetone, the residue was taken up in chloroform and washed with a saturated solution of sodium hydrogen carbonate. The organic phase was dried over anhydrous $\mathrm{MgSO}_{4}$ and the solvent was evaporated to give the product, a pale yellow oil (80\%) which was used directly without further purification. $[\alpha]_{D}^{20}=-41.9$ (c5.25, $\left.\mathrm{CHCl}_{3}\right) .{ }^{1} \mathrm{H}$ NMR: $1.33\left(\mathrm{t}, 6 \mathrm{H}, \mathrm{J}=7.1 \mathrm{~Hz}, \mathrm{CH}_{2} \mathrm{CH}_{3}\right) ; 1.50(\mathrm{~s}$, $\left.6 \mathrm{H}, \mathrm{CH}_{3}\right) ; 4.29\left(\mathrm{q}, 4 \mathrm{H}, \mathrm{J}=7.1 \mathrm{~Hz} \mathrm{CH}_{2} \mathrm{CH}_{3}\right) ; 4.78(\mathrm{~s}, 2 \mathrm{H}, \mathrm{CH}) .{ }^{13} \mathrm{C}$ NMR: $13.90\left(\mathrm{CH}_{3} \mathrm{CH}_{2}\right), 26.20\left(\mathrm{CH}_{3}\right), 61.70\left(\mathrm{CH}_{2}\right), 77.00(\mathrm{CH}), 113.60$ $\left(\mathrm{CMe}_{2}\right), 169.50(\mathrm{CO}) . \mathrm{IR}\left(\mathrm{cm}^{-1}\right): 2988,2942,1757,1385,1375,1260$, $1210,1165,1111,1026 . \mathrm{GC}-\mathrm{MS}(\mathrm{m} / \mathrm{z}): 247\left[(\mathrm{M}+\mathrm{H})^{+}\right], 231,173,161$, $155,145,133,115,104,87,85,83,59,43$.

\section{(S,S)-2,3-O-isopropylidene-butane-1,4-diol [(S,S)-3]}

A solution of of $(R, R)-2(0.13 \mathrm{~mol}, 33.2 \mathrm{~g})$ in $250 \mathrm{ml}$ of THF was cooled to $0{ }^{\circ} \mathrm{C}$ and lithium aluminum hydride $(0.28 \mathrm{~mol}, 10.8 \mathrm{~g})$ was slowly added so that the temperature was maintained below $25^{\circ} \mathrm{C}$. The reaction was stirred overnight at room temperature. At $0{ }^{\circ} \mathrm{C}$, ethyl acetate was slowly added to destroy excess hydride, followed sequentially by water $(10.8 \mathrm{ml}), \mathrm{NaOH}, 15 \%(10.8 \mathrm{ml})$ and water $(32.4 \mathrm{ml})$. The resulting mixture was stirred for $1 \mathrm{~h}$, filtered over celite and dried over anhydrous $\mathrm{MgSO}_{4}$. Evaporation of the solvent under reduced pressure originated the product in $75 \%$ yield, a pale yellow oil, which was used directly without further purification.

By further stirring the aluminum salts residue in ethyl acetate for $2-3 \mathrm{~h}$, an additional batch of product could be obtained. $[\alpha]_{D}^{20}=+3.9\left(\mathrm{c5}, \mathrm{CHCl}_{3}\right) .{ }^{1} \mathrm{H}$ NMR: $1.42\left(\mathrm{~s}, 6 \mathrm{H}, \mathrm{CH}_{3}\right) ; 3.70-3.74(\mathrm{~m}$, $\left.6 \mathrm{H}, \mathrm{CH}_{2} \mathrm{CH}\right) ; 4.95$ (bs, $\left.2 \mathrm{H}, \mathrm{OH}\right) .{ }^{13} \mathrm{C}$ NMR: $26.80\left(\mathrm{CH}_{3}\right), 62.10\left(\mathrm{CH}_{2}\right)$, $78.40(\mathrm{CH}), 109.20\left(\mathrm{CMe}_{2}\right) . \mathrm{IR}\left(\mathrm{cm}^{-1}\right): 3407,2990,2936,2884,1651$, $1570,1454,1412,1377,1252,1219 . \mathrm{GC}-\mathrm{MS}(\mathrm{m} / \mathrm{z}): 147\left[\left(\mathrm{M}-\mathrm{CH}_{3}\right)^{+}\right]$, $131,87,69,59$.

\section{(S,S)-2,3-O-isopropylidene-butane-1,4-diyl ditosylate [(S,S)-4]}

The compound was prepared according to a previously described procedure $^{[8,20]}$ using $(R, R)-3(0.17 \mathrm{~mol}, 27.2 \mathrm{~g})$ to give $80 \%$ of a white solid, m.p. $90-92{ }^{\circ} \mathrm{C} .[\alpha]_{D}^{20}=-12.0\left(c 8.8, \mathrm{CHCl}_{3}\right) .{ }^{1} \mathrm{H}$ NMR: $1.30\left(\mathrm{~s}, 6 \mathrm{H}, \mathrm{CH}_{3}\right) ; 2.46\left(\mathrm{~s}, 6 \mathrm{H}, \mathrm{PhCH}_{3}\right) ; 4.00-4.10\left(\mathrm{~m}, 6 \mathrm{H}, \mathrm{CH}_{2} \mathrm{CH}\right) ; 7.37$ (d, $\left.4 \mathrm{H}, J=8 \mathrm{~Hz}, \mathrm{CH}_{\text {arom }}\right) ; 7.78\left(\mathrm{~d}, 4 \mathrm{H}, J=8 \mathrm{~Hz}, \mathrm{CH}_{\text {arom. }}\right){ }^{13} \mathrm{C}$ NMR: $21.60\left(\mathrm{PhCH}_{3}\right), 26.70\left(\mathrm{CH}_{3}\right), 66.40\left(\mathrm{CH}_{2}\right), 75.00(\mathrm{CH}), 110.80\left(\mathrm{CMe}_{2}\right)$, 128.00 ( $\left.C_{\text {arom. }}\right), 129.90$ ( $\left.C_{\text {arom. }}\right), 132.40$ ( $\left.C_{\text {arom. }}\right), 145.20$ ( $\left.C_{\text {arom. }}\right)$. $\mathrm{C}_{21} \mathrm{H}_{2} \mathrm{O}_{8}^{\circ} \mathrm{S}_{2}$ : calculated: $\mathrm{C}, 53.6 ; \mathrm{H}, 5.57 ; \mathrm{S}, 13.63$; found: $\mathrm{C}, 53.49: \mathrm{H}$, 5.57; S, 14.22. LC-MS (m/z): 471 [(M + 1)], 457, 456, 455, 285, 227, $155,126,113,91,69$.

\section{General procedure for the synthesis of (S,S)-2,3-O- isopropylidene- $\boldsymbol{N}^{\mathbf{1}}, \boldsymbol{N}^{\mathbf{4}}$-butane-1,4-diamines [(S,S)-5]}

To a solution of the amine $(80 \mathrm{mmol})$ in $40 \mathrm{ml}$ of dry isopropanol, $(S, S)-4(4.7 \mathrm{~g}, 10 \mathrm{mmol})$ was added. The resulting solution was heated to reflux in an inert atmosphere until complete consumption of $(S, S)-\mathbf{4}$ as monitored by TLC, usually $24-48$ h. ${ }^{\text {[24] }}$ Following solvent and excess amine evaporation, the resulting oil was taken up in ethyl acetate and treated with a saturated $\mathrm{NaHCO}_{3}$ solution. After further extraction of the aqueous phase with ethyl acetate, the joint organic phases were dried over anhydrous $\mathrm{MgSO}_{4}$, filtered and the solvent removed under reduced pressure. The product was isolated as described below.

\section{(S,S)-2,3-O-isopropylidene- $N^{1}, N^{4}$-dicyclohexylbutane-1,4-diamine} $[(S, S)-5 a]$

The resulting oil crystallized from hexane to give the product, an off-white solid (46\%), m.p.: $54-55^{\circ} \mathrm{C} .[\alpha]_{D}^{20}=-5\left(c 2, \mathrm{CH}_{2} \mathrm{Cl}_{2}\right) .{ }^{1} \mathrm{H}$ NMR: $1.01-1.33\left(\mathrm{~m}, 12 \mathrm{H}, \mathrm{CH}_{2}\right) ; 1.39\left(\mathrm{~s}, 6 \mathrm{H}, \mathrm{CH}_{3}\right) ; 1.71-1.75(\mathrm{~m}, 4 \mathrm{H}$, $\left.\mathrm{CH}_{2}\right) ; 1.86-1.90\left(\mathrm{~m}, 4 \mathrm{H}, \mathrm{CH}_{2}\right) ; 2.18-2.25$ (bs, $\left.2 \mathrm{H}, \mathrm{NH}\right) ; 2.39-2.46(\mathrm{~m}$, $2 \mathrm{H}, \mathrm{CHN}) ; 2.79-2.80\left(\mathrm{~m}, 4 \mathrm{H}, \mathrm{CH}_{2}\right) ; 3.86$ (aprox. t, $2 \mathrm{H}, J=3.45 \mathrm{~Hz}$, $\mathrm{CHO}) .{ }^{13} \mathrm{C}$ NMR: $24.98\left(\mathrm{CH}_{2}\right), 26.06\left(\mathrm{CH}_{2}\right), 27.18\left(\mathrm{CH}_{3}\right), 33.16\left(\mathrm{CH}_{2}\right)$, $33.32\left(\mathrm{CH}_{2}\right), 49.12(\mathrm{CHN}), 57.04\left(\mathrm{CH}_{2} \mathrm{~N}\right), 79.44(\mathrm{CHO}), 108.81\left(\mathrm{CMe}_{2}\right)$. IR $\left(\mathrm{cm}^{-1}\right): 3402,3074,2940,1607,1451,1388,1190,1123,1035$, 1011, 815, 685, 568. LC-MS (m/z): 325(M $\left.{ }^{+}\right), 267,186,140$.

\section{(S,S)-2,3-O-Isopropylidene- $N^{1}, N^{4}$-1,4-dibenzylbutane-1,4-diamine $[(S, S)-5 \mathbf{b}]$}

The resulting oil was chromatographed on silica gel using $\mathrm{CH}_{2} \mathrm{Cl}_{2}-\mathrm{MeOH}(95: 5)$ to give $40 \%$ of the product. $[\alpha]_{D}^{20}=-15.6$ (c2.25, $\left.\mathrm{CH}_{2} \mathrm{Cl}_{2}\right) .{ }^{1} \mathrm{H}$ NMR: $1.38\left(\mathrm{~s}, 6 \mathrm{H}, \mathrm{CH}_{3}\right) ; 1.99$ (bs, 2H, NH); $2.72-2.80\left(\mathrm{~m}, 4 \mathrm{H}, \mathrm{CH}_{2}\right) ; 3.79\left(\mathrm{~s}, 4 \mathrm{H}, \mathrm{CH}_{2}\right) ; 3.93-3.98(\mathrm{~m}, 2 \mathrm{H}, \mathrm{CH})$; 7.17-7.34 (m, 10H, Ph). ${ }^{13} \mathrm{C} \mathrm{NMR:} 27.21\left(\mathrm{CH}_{3}\right), 51.19\left(\mathrm{CH}_{2} \mathrm{~N}\right), 54.03$ $\left(\mathrm{CH}_{2} \mathrm{Ph}\right), 78.75(\mathrm{CH}), 108.76\left(\mathrm{CMe}_{2}\right), 126.94\left(\mathrm{C}_{\text {arom. }}\right), 128.07\left(\mathrm{C}_{\text {arom. }}\right)$, $128.37\left(C_{\text {arom. }}\right), 140.10\left(C_{\text {arom. }}\right)$. IR $\left(\mathrm{cm}^{-1}\right)$ : 3350, 3027, 2930, 1602, $1494,1454,1374,1248,1216,1166,850,820,739,699$. LC-MS $(m / z): 341[(M+1)], 194,148$. 
(S,S)-2,3-O-Isopropylidene- $N^{1}, N^{4}$-bis[(R)-1-phenylethyl]butane-1,4diamine $[(S, S)-5 c]$

The resulting oil was chromatographed on silica gel using $\mathrm{CH}_{2} \mathrm{Cl}_{2}-\mathrm{MeOH}(9: 1)$ to give the product as an oil (40\%). $[\alpha]_{D}^{20}=+30\left(c 2, \mathrm{CH}_{2} \mathrm{Cl}_{2}\right) .{ }^{1} \mathrm{H}$ NMR: $1.30\left(\mathrm{~d}, 6 \mathrm{H}, J=6.4 \mathrm{~Hz}, \mathrm{CH}_{3}\right)$; $1.35\left(\mathrm{~s}, 6 \mathrm{H}, \mathrm{CH}_{3}\right) ; 1.62(\mathrm{bs}, 2 \mathrm{H}, \mathrm{NH}) ; 2.51\left(\mathrm{dd}, 2 \mathrm{H}, J=2.7,12 \mathrm{~Hz}, \mathrm{CH}_{2}\right)$; $2.62\left(\mathrm{dd}, 2 \mathrm{H}, J=5.6,12 \mathrm{~Hz}, \mathrm{CH}_{2}\right) ; 3.69-3.77$ (m, 4H, CHMe, CHO); 7.17-7.32 (m, 10H, Ph). ${ }^{13} \mathrm{C}$ NMR: $24.41\left(\mathrm{CH}_{3}\right), 27.20\left(\mathrm{CH}_{3}\right), 49.47$ $\left(\mathrm{CH}_{2}\right), 58.28(\mathrm{CHMe}), 78.51(\mathrm{CH}), 108.63\left(\mathrm{CMe}_{2}\right), 126.54$ ( $\left.\mathrm{C}_{\text {arom. }}\right)$, $126.89\left(C_{\text {arom. }}\right), 128.41\left(C_{\text {arom. }}\right), 145.41\left(C_{\text {arom. }}\right) . I R\left(\mathrm{~cm}^{-1}\right): 3400$, 3025, 2930, 1640, 1492, 1451, 1370, 1248, 1212, 1169, 845, 761 , 701. LC-MS (m/z): 369 [(M + 1)], 312, 265, 248, 208, 188, 162, 144.

(S,S)-2,3-O-Isopropylidene- $N^{1}, N^{4}$-bis[(S)-1-phenylethyl]butane-1,4diamine $[(S, S)-\mathbf{5 d}]$

The resulting oil was chromatographed on silica gel using AcOEt-MeOH $(95: 5)$ to give the product as an oil (27\%). $[\alpha]_{D}^{20}=-65\left(c 2, \mathrm{CH}_{2} \mathrm{Cl}_{2}\right) .{ }^{1} \mathrm{H}$ NMR: $1.33\left(\mathrm{~d}, 6 \mathrm{H}, J=6.6 \mathrm{~Hz}, \mathrm{CH}_{3}\right)$; $1.36\left(\mathrm{~s}, 6 \mathrm{H}, \mathrm{CH}_{3}\right) ; 2.51\left(\mathrm{dd}, 2 \mathrm{H}, J=4.2,12.3 \mathrm{~Hz}, \mathrm{CH}_{2} \mathrm{~N}\right) ; 2.61(\mathrm{dd}$, $2 \mathrm{H}, J=3.4,12.3 \mathrm{~Hz}, \mathrm{CH}_{2} \mathrm{~N}$ ); $3.73(\mathrm{q}, 2 \mathrm{H}, J=6.6 \mathrm{~Hz}, \mathrm{CHMe}) ; 3.90$ (approx. t, $2 \mathrm{H}, J=2.9 \mathrm{~Hz}, \mathrm{CHO}) ; 7.21-7.31(\mathrm{~m}, 10 \mathrm{H}, \mathrm{Ph}) .{ }^{13} \mathrm{C}$ NMR: $24.41\left(\mathrm{CH}_{3}\right), 27.20\left(\mathrm{CH}_{3}\right), 49.47\left(\mathrm{CH}_{2} \mathrm{~N}\right), 58.28(\mathrm{CHMe}), 78.51$ $(\mathrm{CH}), 108.63\left(\mathrm{CMe}_{2}\right), 126.54\left(C_{\text {arom. }}\right), 126.89\left(C_{\text {arom. }}\right), 128.41\left(C_{\text {arom. }}\right)$, $145.41\left(C_{\text {arom. }}\right)$. IR $\left(\mathrm{cm}^{-1}\right): 3420,3026,2928,1643,1492,1452,1373$, 1248, 1214, 1169, 848, 762, 701. LC-MS (m/z): 369 [(M + 1)], 312, $265,248,208,188,162,144$.

(S,S)-2,3-O-Isopropylidene- $N^{1}, N^{4}$-dimorpholinyl-1,4-butane $\quad[(S, S)$ 5e]

After work-up the resulting solid was recrystallized from hexane to give a white solid (64\%), m.p. $90-92^{\circ} \mathrm{C} .[\alpha]_{D}^{20}=-25(c 2$, $\left.\mathrm{CH}_{2} \mathrm{Cl}_{2}\right) .{ }^{1} \mathrm{H}$ NMR: $1.39\left(\mathrm{~s}, 6 \mathrm{H}, \mathrm{CH}_{3}\right) ; 2.49-2.60\left(\mathrm{~m}, 12 \mathrm{H}, \mathrm{CH}_{2} \mathrm{~N}\right)$; $3.72\left(\mathrm{t}, 4 \mathrm{H}, J=4.8 \mathrm{~Hz}, \mathrm{CH}_{2} \mathrm{O}\right) ; 3.87-3.90(\mathrm{~m}, 2 \mathrm{H}, \mathrm{CH}) .{ }^{13} \mathrm{C} \mathrm{NMR}$ : $27.19\left(\mathrm{CH}_{3}\right), 54.46\left(\mathrm{CH}_{2} \mathrm{~N}\right), 61.48\left(\mathrm{CH}_{2} \mathrm{~N}\right), 66.79\left(\mathrm{CH}_{2} \mathrm{O}\right), 77.53(\mathrm{CH})$, $109.38\left(\mathrm{CMe}_{2}\right) \cdot \mathrm{IR}\left(\mathrm{cm}^{-1}\right): 3465,3431,2976,2960,2891,2858,2808$, $1452,1372,1296,1272,1151,1116,1065,1009,864$. LC-MS (m/z): $301[(M+1)], 243,151$.

\section{Synthesis of (S,S)-2,3-O-isopropylidene-4-(amino)butan-1-ols}

(S,S)-2,3-O-Isopropylidene-4-hydroxy-1-butan-1-yl tosylate [(S,S)-6]

To a solution of $(S, S)-3(2.0 \mathrm{~g}, 12.4 \mathrm{mmol})$ in THF $(40 \mathrm{ml})$ at $-15^{\circ} \mathrm{C}$, was added $n$-BuLi ( $2.5 \mathrm{M}$ in hexane, $4.4 \mathrm{ml}, 11.2 \mathrm{mmol}$ ). The reaction mixture was stirred at room temperature for $30 \mathrm{~min}$. To the resulting solution at $0{ }^{\circ} \mathrm{C}, p$-toluenesulfonylchloride $(2.12 \mathrm{~g}$, $11.2 \mathrm{mmol})$ in THF $(20 \mathrm{ml})$ was added. The reaction was stirred at room temperature for $1 \mathrm{~h}$. After quenching with water, the organic solvent was removed and ether was added to the residue. After washing with brine, the organic phase was dried over $\mathrm{MgSO}_{4}$. Evaporation of the solvent gave the crude product, a mixture of mono and ditosylate, which was purified by column chromatography using AcOEt-hexane (1:1), to give $35 \%$ of the product. $[\alpha]_{D}^{20}=-13.0\left(c 1.15 \mathrm{CH}_{2} \mathrm{Cl}_{2}\right) .{ }^{1} \mathrm{H}$ NMR: $1.35\left(\mathrm{~s}, 3 \mathrm{H}, \mathrm{CH}_{3}\right)$; $1.39\left(\mathrm{~s}, 3 \mathrm{H}, \mathrm{CH}_{3}\right) ; 2.45\left(\mathrm{~s}, 3 \mathrm{H}, \mathrm{CH}_{3} \mathrm{Ph}\right) ; 3.63(\mathrm{dd}, 1 \mathrm{H}, J=3.7,12.1 \mathrm{~Hz}$, $\left.\mathrm{CH}_{2}\right) ; 3.80\left(\mathrm{dd}, 1 \mathrm{H}, J=3.7,12.1 \mathrm{~Hz}, \mathrm{CH}_{2}\right) ; 3.95-4.00(\mathrm{~m}, 1 \mathrm{H}, \mathrm{CH})$; 4.07-4.18 (m, 3H, CH, CH $) ; 7.36(\mathrm{~d}, 2 \mathrm{H}, J=8.0 \mathrm{~Hz}, \mathrm{Ph}) ; 7.78-7.81$ (m, 2H, Ph). ${ }^{13} \mathrm{CNMR}: 21.69\left(\mathrm{CH}_{3} \mathrm{Ph}\right), 26.73\left(\mathrm{CH}_{3}\right), 26.98\left(\mathrm{CH}_{3}\right), 61.60$ $\left(\mathrm{CH}_{2}\right), 68.76\left(\mathrm{CH}_{2}\right), 74.34(\mathrm{CH}), 77.99(\mathrm{CH}), 110.04\left(\mathrm{CMe}_{2}\right), 128.01$ $\left(C_{\text {arom }}\right), 129.94\left(C_{\text {arom }}\right), 132.51\left(C_{\text {arom }}\right), 145.17\left(C_{\text {arom }}\right) . I R\left(\mathrm{~cm}^{-1}\right)$ : 3496, 3456, 3438, 3401, 2989, 1643, 1599, 1097, 555.
(S,S)-2,3-O-Isopropylidene-4-azidobutan-1-ol [(S,S)-7]

To $(S, S)-6(1.2 \mathrm{~g}, 3.9 \mathrm{mmol})$ in $50 \mathrm{ml}$ of DMF, $\mathrm{NaN}_{3}(0.5 \mathrm{~g}, 7.8 \mathrm{mmol})$ was added. The reaction was stirred at $100^{\circ} \mathrm{C}$ in an inert atmosphere overnight. The DMF was removed and ethyl acetate and water were added to the residue. The aqueous phase was further extracted with ethyl acetate, and the organic phases dried over $\mathrm{MgSO}_{4}$. After evaporation of the solvent, the resulting oil was chromatographed on silica gel using AcOEt-hexane $(3: 1)$. The product was obtained in $91 \%$ yield and used directly in the next step. ${ }^{1} \mathrm{H}$ NMR: $1.44\left(\mathrm{~s}, 3 \mathrm{H}, \mathrm{CH}_{3}\right) ; 1.47\left(\mathrm{~s}, 3 \mathrm{H}, \mathrm{CH}_{3}\right) ; 2.90(\mathrm{bs}, 1 \mathrm{H}, \mathrm{OH})$; $3.34\left(\mathrm{dd}, 1 \mathrm{H}, J=4.7,13.1 \mathrm{~Hz}, \mathrm{CH}_{2}\right) ; 3.58(\mathrm{dd}, 1 \mathrm{H}, J=3.9,13.1 \mathrm{~Hz}$, $\left.\mathrm{CH}_{2}\right) ; 3.66\left(\mathrm{dd}, 1 \mathrm{H}, J=4.1,12.0 \mathrm{~Hz}, \mathrm{CH}_{2}\right) ; 3.82(\mathrm{dd}, 1 \mathrm{H}, J=3.7$, $\left.12.0 \mathrm{~Hz}, \mathrm{CH}_{2}\right) ; 3.98-4.03(\mathrm{~m}, 1 \mathrm{H}, \mathrm{CH}) ; 4.07-4.13(\mathrm{~m}, 1 \mathrm{H}, \mathrm{CH}) .{ }^{13} \mathrm{C}$ NMR: $26.87\left(\mathrm{CH}_{3}\right), 27.07\left(\mathrm{CH}_{3}\right), 51.70(\mathrm{CH}), 61.63\left(\mathrm{CH}_{2}\right), 75.97(\mathrm{CH})$, $78.37(\mathrm{CH}), 109.86\left(\mathrm{CMe}_{2}\right) . \mathrm{IR}\left(\mathrm{cm}^{-1}\right): 3512,3446,3338,2987,2935$, 2104, 1371, 1243, 1205, 1077, 1051.

\section{(S,S)-2,3-O-Isopropylidene-4-aminobutan-1-ol [(S,S)-8]}

Azide $(S, S)-7$ (0.47 g, $2.51 \mathrm{mmol})$ was placed in a Parr reactor with $30 \mathrm{ml}$ dry ethanol and $85 \mathrm{mg} \mathrm{Pd} / \mathrm{C}, 10 \%$ at room temperature and $1 \mathrm{~atm}$ hydrogen for $2-3 \mathrm{~h}$. The mixture was filtered over a celite pad, dried over $\mathrm{MgSO}_{4}$ and the solvent evaporated. A pure oil was obtained in $83 \%$ yield. $[\alpha]_{D}^{25}=+20.0\left(c 1.0 \mathrm{CH}_{2} \mathrm{Cl}_{2}\right) .{ }^{1} \mathrm{H}$ NMR: $1.40\left(\mathrm{~s}, 3 \mathrm{H}, \mathrm{CH}_{3}\right) ; 1.43\left(\mathrm{~s}, 3 \mathrm{H}, \mathrm{CH}_{3}\right) ; 2.80(\mathrm{bs}, 1 \mathrm{H}, \mathrm{OH}) ; 3.06-3.11(\mathrm{~m}$, $\left.4 \mathrm{H}, \mathrm{CH}_{2}, \mathrm{NH}_{2}\right) ; 3.62-3.83\left(\mathrm{~m}, 4 \mathrm{H}, \mathrm{CH}, \mathrm{CH}_{2}\right) .{ }^{13} \mathrm{C} \mathrm{NMR:} 26.84\left(\mathrm{CH}_{3}\right)$, $27.01\left(\mathrm{CH}_{3}\right), 43.03\left(\mathrm{CH}_{2}\right), 62.39\left(\mathrm{CH}_{2}\right), 80.95(\mathrm{CH}), 81.06(\mathrm{CH}), 108.66$ $\left(\mathrm{CMe}_{2}\right) . \mathrm{IR}\left(\mathrm{cm}^{-1}\right): 3467,3422,3414,3399,3362,2988,1654,1384$, $1218,1166,1075$.

General procedure for the synthesis of (S,S)-2,3-OIsopropylidene-4-aminobutan-1-ols from [(S,S)-6]

A solution of $(S, S)-6(2.7 \mathrm{~g}, 6.4 \mathrm{mmol})$ and the amine $(25.6 \mathrm{mmol})$ in $25 \mathrm{ml}$ dry isopropanol was refluxed for $24 \mathrm{~h}$. The solvent was evaporated and ethyl acetate and water were added. The aqueous phase was extracted three times with ethyl acetate and the joint organic phases dried over $\mathrm{MgSO}_{4}$. After evaporating the solvent, the product was purified as described below.

\section{(S,S)-2,3-O-isopropylidene-4-(cyclohexyl)aminobutan-1-ol [(S,S)-9]}

The product was purified by column chromatography using AcOEt $-\mathrm{MeOH}(95: 5)$ to give a solid with $33 \%$ yield. m.p.: $63-65^{\circ} \mathrm{C}$. $[\alpha]_{D}^{20}=+55.0\left(\mathrm{c} 1.0 \mathrm{CH}_{2} \mathrm{Cl}_{2}\right) .{ }^{1} \mathrm{H}$ NMR: $1.03-1.39\left(\mathrm{~m}, 5 \mathrm{H}, \mathrm{CH}_{2}\right) ; 1.38$ $\left(\mathrm{s}, 3 \mathrm{H}, \mathrm{CH}_{3}\right) ; 1.41\left(\mathrm{~s}, 3 \mathrm{H}, \mathrm{CH}_{3}\right) ; 1.60-1.73\left(\mathrm{~m}, 3 \mathrm{H}, \mathrm{CH}_{2}\right) ; 1.90-1.96$ $\left(\mathrm{m}, 2 \mathrm{H}, \mathrm{CH}_{2}\right) ; 2.41-2.49(\mathrm{~m}, 1 \mathrm{H}, \mathrm{CHN}) ; 2.61(\mathrm{dd}, 1 \mathrm{H}, J=9.8,11.9 \mathrm{~Hz}$, $\left.\mathrm{CH}_{2} \mathrm{~N}\right) ; 3.18\left(\mathrm{dd}, 1 \mathrm{H}, J=3.6,11.9 \mathrm{~Hz}, \mathrm{CH}_{2} \mathrm{~N}\right) ; 3.52(\mathrm{dd}, 1 \mathrm{H}, J=8.3$, $\left.10.2 \mathrm{~Hz}, \mathrm{CH}_{2} \mathrm{O}\right) ; 3.67-3.86\left(\mathrm{~m}, 3 \mathrm{H}, \mathrm{CH}_{2} \mathrm{O}, \mathrm{CH}\right) .{ }^{13} \mathrm{C} \mathrm{NMR:} 24.89\left(\mathrm{CH}_{3}\right)$, $25.80\left(\mathrm{CH}_{3}\right), 26.71\left(\mathrm{CH}_{2}\right), 26.90\left(\mathrm{CH}_{2}\right), 33.04\left(\mathrm{CH}_{2}\right), 33.45\left(\mathrm{CH}_{2}\right)$, $47.73\left(\mathrm{CH}_{2} \mathrm{~N}\right), 56.90(\mathrm{CHN}), 62.40\left(\mathrm{CH}_{2} \mathrm{O}\right), 80.93(\mathrm{CHO}), 82.04(\mathrm{CHO})$, $108.45\left(\mathrm{CMe}_{2}\right) . \mathrm{IR}\left(\mathrm{cm}^{-1}\right): 3356,3271,3126,2927,2855,1454,1375$, $1247,1220,1107,1073,995,849$. GC-MS $(\mathrm{m} / \mathrm{z}): 226\left[\left(\mathrm{M}-\mathrm{CH}_{3}\right)^{+}\right]$, $154,142,112,83,55$.

\section{(S,S)-2,3-O-Isopropylidene-4-(benzyl)aminobutan-1-ol [(S,S)-10]}

The oil was purified by column chromatography using AcOEt-MeOH $(90: 10)$ to give the product with $48 \%$ yield. $[\alpha]_{D}^{20}=+37.5\left(c 2.0 \mathrm{CH}_{2} \mathrm{Cl}_{2}\right) .{ }^{1} \mathrm{H}$ NMR: $1.38\left(\mathrm{~s}, 3 \mathrm{H}, \mathrm{CH}_{3}\right) ; 1.40(\mathrm{~s}, 3 \mathrm{H}$, $\left.\mathrm{CH}_{3}\right) ; 2.70\left(\mathrm{dd}, 1 \mathrm{H}, J=8.2,12.0 \mathrm{~Hz}, \mathrm{CH}_{2} \mathrm{~N}\right) ; 3.07(\mathrm{dd}, 1 \mathrm{H}, J=3.7$, $\left.12.0 \mathrm{~Hz}, \mathrm{CH}_{2} \mathrm{~N}\right) ; 3.59\left(\mathrm{dd}, 1 \mathrm{H}, J=8.2,11.9 \mathrm{~Hz}, \mathrm{CH}_{2} \mathrm{O}\right) ; 3.76-3.84(\mathrm{~m}$, 
$\left.5 \mathrm{H}, \mathrm{CH}_{2} \mathrm{O}, \mathrm{CHPh}, \mathrm{CH}\right) ; 7.26-7.34(\mathrm{~m}, 5 \mathrm{H}, \mathrm{Ph}) .{ }^{13} \mathrm{C} \mathrm{NMR}: 26.74\left(\mathrm{CH}_{3}\right)$, $26.93\left(\mathrm{CH}_{3}\right), 50.22\left(\mathrm{CH}_{2}\right), 54.05\left(\mathrm{CH}_{2}\right), 62.33\left(\mathrm{CH}_{2}\right), 79.47(\mathrm{CH}), 81.40$ $(\mathrm{CH}), 108.59\left(\mathrm{CMe}_{2}\right), 127.48\left(C_{\text {arom }}\right), 128.27\left(C_{\text {arom }}\right), 128.64\left(C_{\text {arom }}\right)$, $138.64\left(C_{\text {arom }}\right)$. IR $\left(\mathrm{cm}^{-1}\right): 3415,2986,2933,1454,1383,1371,1217$, 1167, 1074, 1058, 699. GC-MS (m/z): $236\left[\left(\mathrm{M}-\mathrm{CH}_{3}\right)^{+}\right], 120,114$, $106,91,59$.

\section{(S,S)-2,3-O-Isopropylidene-4-[(S)-1-phenylethyl]amino]butan-1-ol} [(S,S)-11]

The oil was purified by column chromatography using AcOEt-MeOH $(95: 5)$ to give the product with $43 \%$ yield. $[\alpha]_{D}^{20}=-10\left(\mathrm{c} 2.0 \mathrm{CH}_{2} \mathrm{Cl}_{2}\right) .{ }^{1} \mathrm{H}$ NMR: $1.34\left(\mathrm{~s}, 3 \mathrm{H}, \mathrm{CH}_{3}\right) ; 1.38(\mathrm{~s}$, $\left.3 \mathrm{H}, \mathrm{CH}_{3}\right) ; 1.40\left(\mathrm{~d}, 3 \mathrm{H}, J=6.6 \mathrm{~Hz}, \mathrm{CH}_{3}\right) ; 2.56(\mathrm{dd}, 1 \mathrm{H}, J=8.5$, $\left.12.0 \mathrm{~Hz}, \mathrm{CH}_{2} \mathrm{~N}\right) ; 2.86\left(\mathrm{dd}, 1 \mathrm{H}, J=4.0,12.0 \mathrm{~Hz}, \mathrm{CH}_{2} \mathrm{~N}\right) ; 3.53-3.84$ (m, 5H, CH $\left.\mathrm{H}_{2} \mathrm{O} \mathrm{CH}\right) ; 7.24-7.35(\mathrm{~m}, 5 \mathrm{H}, \mathrm{Ph}) .{ }^{13} \mathrm{C} \mathrm{NMR}: 23.27\left(\mathrm{CH}_{3}\right)$, $26.70\left(\mathrm{CH}_{3}\right), 26.89\left(\mathrm{CH}_{3}\right), 48.90\left(\mathrm{CH}_{2}\right), 58.76(\mathrm{CH}), 62.24\left(\mathrm{CH}_{2}\right), 79.78$ $(\mathrm{CH}), 81.29(\mathrm{CH}), 108.51\left(\mathrm{CMe}_{2}\right), 126.34\left(\mathrm{C}_{\text {arom }}\right), 128.70\left(\mathrm{C}_{\text {arom }}\right)$, $129.88\left(C_{\text {arom }}\right), 143.98\left(C_{\text {arom }}\right)$. IR $\left(\mathrm{cm}^{-1}\right): 3416,2984,2932,2870$, $1453,1371,1217,1168,1058,868,847,763,702$. GC-MS (m/z): 250 $\left[\left(\mathrm{M}-\mathrm{CH}_{3}\right)^{+}\right], 192,134,120,114,105,91,77,59$.

\section{(S,S)-2,3-O-Isopropylidene-4-morpholinylbutan-1-ol [(S,S)-12]}

The residue was purified by column chromatography using $\mathrm{CH}_{2} \mathrm{Cl}_{2}-\mathrm{MeOH}-\mathrm{NH}_{3}(150: 8: 1)$ to give the product with $39 \%$ yield. $[\alpha]_{D}^{25}=+15.0\left(\mathrm{c} 1.0 \mathrm{CH}_{2} \mathrm{Cl}_{2}\right) .{ }^{1} \mathrm{H} \mathrm{NMR}\left(\mathrm{CDCl}_{3}\right): 1.39\left(\mathrm{~s}, 3 \mathrm{H}, \mathrm{CH}_{3}\right) ; 1.40$ $\left(\mathrm{s}, 3 \mathrm{H}, \mathrm{CH}_{3}\right) ; 2.49-2.57\left(\mathrm{~m}, 3 \mathrm{H}, \mathrm{CH}_{2} \mathrm{~N}\right) ; 2.65-2.76\left(\mathrm{~m}, 3 \mathrm{H}, \mathrm{CH}_{2} \mathrm{~N}\right)$; $3.57-3.62(\mathrm{~m}, 1 \mathrm{H}, \mathrm{CH}) ; 3.72\left(\mathrm{t}, 4 \mathrm{H}, J=4.7 \mathrm{~Hz}, \mathrm{CH}_{2} \mathrm{O}\right) ; 3.74-3.80$ $\left(\mathrm{m}, 2 \mathrm{H}, \mathrm{CH}_{2} \mathrm{O}\right) ; 3.87-3.91(\mathrm{~m}, 1 \mathrm{H}, \mathrm{CH}) .{ }^{13} \mathrm{C} \mathrm{NMR}\left(\mathrm{CDCl}_{3}\right): 26.75$ $\left(\mathrm{CH}_{3}\right), 26.94\left(\mathrm{CH}_{3}\right), 54.37\left(\mathrm{CH}_{2} \mathrm{~N}\right), 60.52\left(\mathrm{CH}_{2} \mathrm{~N}\right), 62.38\left(\mathrm{CH}_{2} \mathrm{O}\right), 66.49$ $\left(\mathrm{CH}_{2} \mathrm{O}\right), 77.85(\mathrm{CH}), 81.66(\mathrm{CH}), 108.83\left(\mathrm{CMe}_{2}\right) . \mathrm{IR}\left(\mathrm{cm}^{-1}\right)$ : 3461, $2865,1737,1646,1454,1375,1240,1114,1066,860$. GC-MS (m/z): $216\left[\left(\mathrm{M}-\mathrm{CH}_{3}\right)^{+}\right], 156,100,70,56$.

\section{General procedure for enantioselective alkylations}

To the chiral ligand $(0.15 \mathrm{mmol})$ and the aldehyde $(1 \mathrm{mmol})$ in an inert atmosphere, $4 \mathrm{ml}$ cyclohexane were added. The temperature of the reaction mixture was lowered to $0{ }^{\circ} \mathrm{C}$ and diethylzinc $(2 \mathrm{ml}$ of a $1 \mathrm{~m}$ hexane solution, $2 \mathrm{mmol}$ ) was added. The reaction was stirred at the same temperature for $24 \mathrm{~h}$. After this time, a saturated ammonium chloride solution ( $1 \mathrm{ml}$ ) followed by $2 \mathrm{M} \mathrm{HCl}(1 \mathrm{ml}$ ) were added and the reaction mixture was extracted with diethyl ether. The organic phases were washed with water and brine and dried over anhydrous $\mathrm{MgSO}_{4}$. The resulting solution was analyzed by $\mathrm{GC}$ in order to determine the conversion and percentage of chiral alcohol. The ee of the chiral alcohol was determined by GC using a chiral $\gamma$-cycldextrin column.

\section{Acknowledgments}

The authors would like to thank Chymiotechnon and FCT (POCI/QUI/55931/2004) for financial support.

\section{References}

[1] L. Pu, H.-B. Yu, Chem. Rev. 2001, 101, 757-824.

[2] G.-Q.Lin, Y.-M. Li, A.S.C.Chan, Principles and Applications of Asymmetric Synthesis. Wiley: New York, 2001, chapter 2.

[3] F. Fache, E. Schulz, M. L. Tommasino, M. Lemaire, Chem. Rev. 2000, $100,2159-2231$.

[4] H. B. Kagan, T. O. Luukas. General Aspects of Asymmetric Catalysis. In Comprehensive Asymmetric Catalysis (Eds: E. N. Jacobsen, A. Pfaltz and $\mathrm{H}$. Yamamoto). Springer: Berlin, 1999, vol. l, chapter 4.

[5] A. H. Haines, C. Morley, B. A. Murrer, J. Med. Chem. 1989, 32, $742-745$.

[6] D.-K. Kim, G. Kim, J. Gam, Y.-B. Cho, H.-T. Kim, J.-H. Tai, K. H. Kim, W.-S. Hong, J.-G. Park, J. Med. Chem. 1994, 37, 1471-1485.

[7] B. A. Shainyan, M. V. Ustinov, V. K. Bel'skii, L. O. Nindakova, Russ. J. Org. Chem. 2002, 38, 104-110.

[8] L. O. Nindakova, N. N. Chipanina, V. K. Turchaninov, M. V. Ustinov, B. A. Shainyan, Russ. Chem. Bull., Int. Edn 2005, 54, 2343-2347.

[9] B. A. Shainyan, L. O. Nindakova, M. V. Ustinov, N. N. Chipanina, L. V. Sherstyannikova, Russ. J. Org. Chem. 2002, 38, 1802-1805.

[10] B. A. Shainyan, M. V. Ustinov, L. O. Nindakova, Russ. J. Org. Chem. 2001, 37, 1757-1761.

[11] M. Iglesias, D. J. Beetstra, A. Stasch, P. N. Horton, M. B. Hursthouse, S. J. Coles, K. J. Cavell, A. Dervisi, I. A. Fallis, Organometallics 2007, $26,4800-4809$

[12] N. G. Luk'yanenko, A. V. Lobach, O. N. Leus, Russ. J. Org. Chem. 2003, 39, 1042-1047.

[13] F. Robert, F. Delbecq, C. Nguefack, D. Sinou, Eur. J. Inorg. Chem. 2000, 351-358.

[14] A. Trabocchi, G. Menchi, M. Rolla, F. Machetti, I. Bucelli, A. Guarna, Tetrahedron 2003, 59, 5251-5258.

[15] H. B. Kagan, T. P. Dang, J. Am. Chem. Soc. 1972, 94, 6429-6433.

[16] C.T.Quian, F. F. Gao, J. Sun, Tetrahedron, Asymmetry 2000, 11, $1733-1740$.

[17] D. Seebach, A. K. Beck, A. Heckel, Angew. Chem. Int. Ed. 2001, 40, 92-138.

[18] L. J. Rubin, H. A. Lardy, H. O. L. Fischer, J. Am. Chem. Soc. 1952, 74, 425-428.

[19] P. W. Feit, J. Med. Chem. 1964, 7, 14-17.

[20] M. Carmack, C. J. Kelley, J. Org. Chem. 1968, 33, 2171-2173.

[21] D. Seebach, H. O. Kalinowski, B. Bastani, G. Crass, H. Daum, H. Dörr, N. P. DuPreez, V. Ehrig, W. Langer, C. Nüssler, H. A. Oei, M. Schmidt, Helv. Chim. Acta 1977, 60, 301-325.

[22] A. E. Wróblewski, I. E. Glowacka, Tetrahedron 2005, 61, $11930-11938$.

[23] B. A. Murrer, J. M. Brown, P. A. Chaloner, P. N. Nicholson, D. Parker, Synthesis 1979, 350-352.

[24] B. T. Cho, N. Kim, J. Chem. Soc., Perkin Trans. 1 1996, 2901-2907.

[25] H. Kotsuki, I. Kadota, M. Ochi, J. Org. Chem. 1990, 55, 4417-4422.

[26] D. S. Bose, M. K. Gurjar, Synth. Comm. 1989, 19, 3313-3321.

[27] A. M. d'A. Rocha Gonsalves, M. E. S. Serra, D. Murtinho, V. F. Silva, M. R. Silva, A. M. Beja, J. A. Paixão, M. R. Silva, L. Alte da Veiga, J. Molec. Cat. A, Chem. 2003, 195, 1-9.

[28] M. Asami, H. Watanabe, K. Honda, S. Inoue, Tetraheron, Asymmetry $1998,9,4165-4173$.

[29] M. R. Paleo, I. Cabeza, F. J. Sardina, J. Org. Chem. 2000, 65, $2108-2113$

[30] S. Vyskocil, S. Jaracz, M. Smrcina, M. Stícha, V. Hanus, M. Polasek, P. Kocovsky, J. Org. Chem. 1998, 63, 7727-7737.

[31] L. Solà, K. S. Reddy, A. Vidal-Ferran, A. Moyano, M. A. Pericàs, A. Riera, A. Alvarez-Larena, J. F. Piniella, J. Org. Chem. 1998, 63, $7078-7082$ 